\title{
ACRL COMMITTEE VOLUNTEER FORM
}

If you are interested in serving on an ACRL standing committee, please complete this form and mail it before the ALA Midwinter Meeting to: Russell Shank, University Librarian, UCLA, 405 Hilgard Ave., Los Angeles, CA 90024.

If you would like to serve on an ACRL section committee, send this form to the appropriate section vice-chair/chair-elect before the ALA Midwinter Meeting.

NAME, TITLE, INSTITUTIONAL ADDRESS

PREFERRED MAILING ADDRESS

DATE OF APPLICATION

NUMBER OF YEARS AS MEMBER OF ALA ACRL

ACADEMIC BACKGROUND (List institutions, dates of degrees, and relevant subject areas)

PROFESSIONAL ACTIVITIES

ALA or ACRL Committee Assignments

ALA or ACRL Offices Held

Publications
State and Regional Committee Assignments

State and Regional Offices Held

Other

ACRL COMMITTEE PREFERENCES

RELEVANT BACKGROUND OR EXPERIENCE FOR COMMITTEE ASSIGNMENT

Can you attend regularly the ALA Midwinter and Annual conferences? YES __ NO PLEASE EXPRESS YOUR MAJOR CONCERNS FOR STRENGTHENING THE ASSOCIATION OF COLLEGE AND RESEARCH LIBRARIES: 